\title{
For God and Country: Faith and Patriotism Under Fire
}

Authors: James Yee and Aimee Malloy. Publisher: Public Affairs, October 2005. ISBN 1586483692 hardback, $240 \mathrm{pp}$.

1 he military prison at Guantanamo Bay, Cuba, serves as the backdrop for James Yee's memoir detailing his service as a United States Army Muslim chaplain and his subsequent arrest on capital charges. Looming in the foreground is a chronicle of the xenophobic governmental abuse and ineptitude that has characterized the "War on Terror."

On September 10, 2003, upon arriving at the Jacksonville, Florida, naval base after having served as Guantanamo Bay's Muslim chaplain for the previous 10 months, Yee's bags were subject to a routine search. What followed, however, was far from routine. Yee writes, "I still don't understand how the misguided suspicions of a few inexperienced soldiers led to the ordeal that...changed my life, tore apart my family, and destroyed my military career." After searching his bags, agents from the Naval Criminal Investigative Service (NCIS) took Yee into custody and locked him into a small, maximum-security cell at the Jacksonville naval brig. Later that day a guard pounded on Yee's cell door. "Do you know why you are here?" he asked, and then proceeded to read from a clipboard that Yee was charged with aiding the enemy, spying, espionage, sedition, mutiny, and failure to obey a lawful general order. The charges were shocking to Yee, because he believed that he was the most unlikely of traitors.

Born in 1968 in suburban Springfield, New Jersey, a second-generation American, Yee describes his family as "terribly American." His father was drafted into the army after high school and just missed fighting in World War II. Yee continued this tradition of military service when he graduated from the United States Military Academy at West Point, New York. After commencement, he traveled to Washington D.C. to meet a friend, and it was on this occasion that his interest in Islam was piqued. Yee, a Lutheran at this time, engaged in a debate concerning the doctrine of the Trinity with his friend's roommate. This debate served as a catalyst for his continuing inter- est in Islam. He notes that he never intended to convert to Islam, but he became increasingly drawn to the simplicity of the religion. He formally converted in April 1991 and set off for his first military assignment in Germany shortly afterward. During Operation Desert Storm he was stationed in Saudi Arabia and visited Makka, Islam's holiest of cities. Yee's description of his visit to Makka is reminiscent of Malcolm X's trip to the city in the early 1960s, which was chronicled in his autobiography. Both men were astonished by the diversity of the Muslims visiting the holy city. Yee writes that, "It was one of the most eye-opening experiences of my life. The diversity of Islam was incredible."

This visit proved to be a seminal event in Yee's young life. He was becoming increasingly interested in becoming a Muslim chaplain for the military. However, it was not until he performed the Hajj, the pilgrimage to Makka, that he decided to dedicate his life to the study of Islam with the goal of becoming a Muslim chaplain. He enrolled in a program to study Arabic and religious studies at Abu Noor University in Damascus, Syria. After four years in Syria, Yee had married a Syrian woman and felt confident in the knowledge gained in his studies to apply to become a Muslim chaplain. His application was accepted, and he was assigned as the battalion chaplain at Fort Lewis, Washington. Five months later, planes were flown into the World Trade Center and the Pentagon and his life was to take yet another turn.

It is this turn that should make the book of interest to policymakers and social activists. A year after the September 11 attacks, Yee was ordered to report to Guantanamo Bay where he was to serve a sixmonth assignment as the Army Muslim chaplain. James Baldwin, the New York literary voice of the civil rights era, once said that American history is longer, larger, more various, more beautiful and more terrible than anything anyone has ever said about it. Yee's retelling of his experience at Guantanamo Bay encompasses all of these elements in the short history of America's War on Terror.

"We say the War on Terror is not a war against Islam, but that is not how it felt most days [in 
Guantanamo Bay]," Yee affirms. He describes the place replete with contradictions. The prisoners at Guantanamo Bay were labeled enemy combatants and consequently were denied the rights given to prisoners of war. The Muslim chaplain whom Yee replaces warns him without equivocation that the naval station was hostile to all Muslims, prisoners, and personnel alike. Yee questions the veracity of this warning until he visits the cells of the prisoners and witnesses the guards' treatment of the prisoners and the Muslim staff.

When describing the prisoners and their situation Yee's narrative assumes a sympathetic tone, which is obviously due to his own arrest. He muses, "I expected to come face to face with Osama bin Ladens, but most prisoners were friendly and seemed overjoyed to see me." He was appalled by the harsh conditions in which the prisoners were held. Each man was held in an 8-foot by 6-foot open-air cage with a small bed, sink and an Eastern-style toilet. The prisoners were only allowed out of their cages for 15 minutes every 3 days.

At the time of Yee's assignment there were 660 prisoners held at Guantanamo Bay. Contrary to popular belief, many of these men did not hail from predominantly Muslim countries. Several of these men were Chinese, Australian, French, and British nationals. Yee developed a rapport with several of the men from Great Britain who were held at the prison. These men described their arrests as serious mistakes and said that they had never met Osama bin Laden and were not members of al-Qaeda. In the course of a visit with one of the British prisoners, the man told Yee that, "I think what happened on September 11 was terrible. But, suggesting I was someway linked to it, when I'm innocent, is just wrong." Yee left that encounter determined not to get involved in any further discussions about any of the prisoners' guilt or innocence. He wanted it made clear that he had no influence over their release. But as time progressed, it becomes increasingly clear that Yee believed that many of the prisoners were innocent. He reported that an Arabic translator at the prison commented, "half of the prisoners should be sent home."

In stark contrast to his description of the prisoners is Yee's description of the guards and the other non-Muslim personnel. He portrays them as an arbitrary and completely inept lot whose primary goal was simply to antagonize the prisoners. "Most of the personnel were reservists operating with little guidance. Schoolteachers with a few weeks training were responsible for the camp's physical security, most interpreters had no linguistic training." From Yee's perspective, the oppressive treatment the prisoners received at the hands of the guards was more appalling then the ineptitude of the military personnel. "The soldiers would get pumped up, and many came to work looking for trouble." In many cases, he adds, punishment assumed the form of physical violence. In other instances, soldiers would employ psychological methods to punish or antagonize the prisoners. Female soldiers were used to search the prisoners in inappropriate ways, the mașāhif (written versions of the Qur'an) of the prisoners were routinely desecrated, and during interrogation sessions, Yee writes that a detainee told him that the interrogators forced the prisoners to say that "Satan is your God, not Allah."

Witnessing this treatment of the prisoners wore on Yee's psyche, and he began to question his role at the prison. Was it a merely a political appointment to give the appearance to outsiders that the government was truly tolerant and sensitive to Muslims and Islam? he asked himself. This dilemma resulted in Yee in assuming a more active role as chaplain. He began to document abuses and report them to his superiors. He believes that if he had not been present at the time, the situation at Guantanamo would have worsened. However, it was his involvement that led his superiors to question his motives, which ultimately resulted in his arrest at Jacksonville.

Yee's memoir is unique in that it paints a portrait of the War on Terror, using Guantanamo Bay as a backdrop, from both an outsider's and insider's perspective. Yee began his sojourn as outsider peering into the lives of the prisoners held at Guantanamo; he ended up in the same situation as the prisoners he had been given the task of counseling.

\section{Submitted by}

\section{Kim Searcy, $\mathrm{PhD}$}

Assistant Professor, Department of History

Loyola University-Chicago

Chicago, Illinois

Professor Searcy has a PhD in Near Eastern Languages and Culture from Indiana University. 